\title{
GAYA MENGAJAR DOSEN UNTUK MENINGKATKAN HASIL BELAJAR MAHASISWA
}

\author{
Sri Indah Pujiastuti \\ e-mail: sriindahpujiastuti@gmail.com \\ PG PAUD FIP Universitas Negeri Jakarta
}

\begin{abstract}
Abstrak: Penelitian ini dilakukan untuk mengetahui gaya mengajar dosen Pendidikan Anak Usia Dini (PAUD), Fakultas Ilmu Pendidikan (FIP), Universitas Negeri Jakarta (UNJ) dilihat dari 4 tipe, yaitu formal authority, personal model atau demonstrator, fasilitator, dan delegator. Penelitian ini dilakukan di UNJ, FIP, Jurusan/Program Studi PAUD. Penelitian yang dilakukan dalam September 2011 sampai dengan Januari 2012 ini, menggunakan metode kualitatif deskriptif. Instrumen penelitian adalah peneliti sendiri. Teknik pengumpulan data menggunakan observasi, wawancara, dan dokumentasi. Teknik keabsahan data menggunakan triangulasi dan member check. Analisis data menggunakan langkah-langkah reduksi data, display data, dan verifikasi/kesimpulan. Hasil penelitian ini adalah kecenderungan dosen PG PAUD FIP UNJ menggunakan gaya mengajar fasilitator dengan pembelajaran berpusat pada mahasiswa, dan dosen memberikan berbagai kegiatan yang dapat dilakukan oleh mahasiswa untuk meningkatkan dan mengembangkan kemampuan mahasiswa. Lebih lanjut disarankan dosen meningkatkan komptensi yang berkaitan dengan profesinya.
\end{abstract}

Kata kunci: gaya mengajar, dosen, formal authority, personal model, demonstrator, fasilitator, delegator, kompetensi profesi dosen.

\section{STAFF'S LECTURING STYLES TO IMPROVE STUDENTS' LEARNING OUTCOME}

\begin{abstract}
This research aimed at discovering the staff's lecturing styles at The Early Childhood Education Program, The School of Education, The State University of Jakarta based on four types: formal authority, personal model or demonstrator, fasilitator, dan delegator. The research conducted in September2011 through January 2012, employed descriptive qualitative method with the researcher acting as the instrument. Data were collected by observation, interview, and document study techniques to be validated in triangulation and member check. Data analysis used the procedures of data reduction, data display, and verification/conclusion. The findings indicate that the staff tend to practise facilitator lecturing style oriented on the students and the staff initate various activities involving the students to improve and develop their competence. Based on the research findings, the staff are recommended to improve their professional competence properly.
\end{abstract}

Keywords: lecturing styles, staff, formal authority, personal model, demonstrator, fasilitator, delegator, professional competence

\section{LATAR BELAKANG}

\section{Latar Belakang}

Gaya mengajar setiap dosen di PG PAUD FIP UNJ bervariasi, namun masih banyak dosen yang memiliki gaya mengajar yang monoton. Dosen tersebut hanya menggunakan satu gaya saja sehingga mahasiswa cenderung bosan, dan enggan melaksanakan tugas-tugas pembelajaran secara maksimal. Misalnya, masih banyak dosen hanya menggunakan gaya formal authority misalnya. Dosen hanya memberikan perintah untuk melaksanakan tugas tetapi tidak diberikan contoh dan arahan pengetahuan yang jelas, sehingga mahasiswa bingung dengan tugas mereka, dan hasil belajar mahasiswa tidak maksimal. Jika tingkat intelektual mahasiswa sangat terbatas atau pas-pasan, maka gaya mengajar dosen tersebut kurang berhasil dilakukan.

Adapula dosen, yang gaya mengajarnya sudah baik, misalnya menggunakan gaya demonstrator. Namun, ini pun masih kurang maksimal karena dosen banyak memberikan contoh, sehingga mahasiswa merasa sudah puas hanya mendapatkan pengetahuan sampai di situ, tidak menggali lebih dalam dari apa yang diberikan oleh dosen. Hasil belajar mahasiswa bisa tinggi hanya terbatas pada mampu menjawab 
soal yang terkait dengan pembahasan materi perkuliahan. Namun, pengetahuan secara menyeluruh, dan mendalam yang berguna bagi aplikasi di masyarakat kurang dirasakan oleh mahasiswa. Hal ini disebabkan gaya demonstrator masih berpusat pada dosen, sehingga kecenderungan aktif adalah dosen, bukan mahasiswa.

Selain gaya demonstrator, adapula dosen yang menggunakan gaya fasilitator. Dosen memberikan fasilitas pada mahasiswa dalam pembelajaran. Semua alat dan bahan disiapkan oleh dosen, mahasiswa yang mengolah, menganalisis, dan menemukan pengetahuan dari apa yang mereka pelajari sendiri. Namun, dengan tingkat pemahaman mahasiswa yang berbedabeda, kadang mahasiswa tidak mengerti bagaimana cara menggunakan dan memaksimal alat dan bahan yang diberikan oleh dosen, sehingga hasil belajar mahasiswa tidak maksimal. Akhirnya, dosen yang peka akan memberikan pengarahan secara behavioristik sampai mahasiswa mengerti cara menggunakan dan mengoptimalkan alat dan bahan yang diberikan.

Terakhir adalah gaya mengajar yang bersifat mendelegasikan. Gaya mengajar ini jarang dilakukan oleh dosen karena membutuhkan tingkat kognitif, afektif, dan psikomotor mahasiswa yang tinggi. Dosen hanya mendelegasikan tugas-tugas individu dan kelompok secara garis besar, lalu mahasiswa yang menyediakan semua alat dan bahan, serta analisis masalahnya bahkan harus kreatif atau mampu menciptakan alat dan bahan tertentu untuk memecahkan masalah.

Dengan karakteristik dan kemampuan mahasiswa yang berbeda-beda bahkan cenderung rendah, maka gaya mendelegasikan ini terlihat kurang berhasil karena sangat membutuhkan kreativitas dari mahasiswa itu sendiri dalam mempelajari pengetahuan. Oleh sebab itu, masih diperlukan gaya-gaya mengajar yang lain untuk dimodifikasi agar hasil belajar mahasiswa dapat ditingkatkan. Oleh karena itu, diperlukan penelitian lebih lanjut mengenai gaya mengajar dosen PG PAUD FIP UNJ. Berdasarkan latar belakang masalah di atas, maka peneliti tertarik untuk meneliti daya mengajar dosen PG PAUD FIP UNJ untuk menggambarkan kecenderungan gaya mengajar dosen $P G$ PAUD FIP UNJ selama ini.

\section{Rumusan Masalah}

Berdasarkan konteks penelitian tersebut, maka fokus permasalahan tersebut adalah: "Bagaimana gaya mengajar dosen PG PAUD FIP UNJ?" Masalah tersebut dijabarkan ke dalam pertanyaan penelitian sebagai berikut: (1) bagaimana gaya mengajar formal authority dosen PG PAUD FIP UNJ, (2) bagaimana gaya mengajar demonstrator atau personal model dosen PG PAUD FIP UNJ, (3) bagaimana gaya mengajar fasilitator dosen PG PAUD FIP UNJ, (4) bagaimana gaya mengajar delegator dosen PG PAUD FIP UNJ?

\section{Kajian Teori}

Gaya mengajar menurut Felder \& Soloman (1992) terdiri dari 4 model, yaitu: (1) Formal Authority: A instructor-centered approach where the instructor feels responsible for providing and controlling the flow of content which the student is to receive and assimilate. The formal authority figure does not concern himself with creating a relationship with the student nor is it important if the students build relationships with each other; (2) Demonstrator or Personal Model: A instructor-centered approach where the instructor demonstrates and models what is expected (skills and processes) and then acts as a coach or guide to assist the students in applying the knowledge. This style encourages student participation and utilizes various learning styles; (3) Facilitator: A student centered approach where the instructor facilitates and focuses on activities. Responsibility is placed on the students to take initiative to achieve results for the various tasks. Students who are independent, active, collaborative learners learners thrive in this environment. Instructors typically design group activities which necessitate active learning, student-to-student collaboration and problem solving; (4) Delegator: A student-centered approach whereby the instructor delegates and places much control and responsibility for learning on individuals or groups of students. This type of instructor will often require students to design and implement a complex learning project and will act solely in a consultative role. Students are often asked to work independently or in groups and must be able to effectively work in group situations and manage various interpersonal roles.

Secara umum keempat gaya mengajar tersebut berbeda-beda satu sama lain, namun dapat saling melengkapi. Pada gaya formal authority lebih cenderung guru yang lebih aktif, sehingga anak-anak kurang diberdayakan kemampuannya. Guru sering bertindak otoriter kepada anak-anak, sehingga anak harus menurut dan patuh oleh apa yang diperintahkan guru. Pada gaya demonstrator, guru cenderung menjadi contoh teladan atau mencontohkan segala perilaku dan kegiatan yang akan dilakukan. Jadi, ide pemikiran selalu dimulai dari guru, bukan dari anak-anak. Anak akan melakukan seperti yang dicontohkan oleh guru. Pada gaya fasilitator, guru cenderung menyediakan apa yang anak butuhkan. Ide pemikiran dapat bermula dari guru atau pun anak. Anak dipacu untuk kreatif dari bahan dan alat yang disediakan oleh guru, dan guru hanya mengarahkan bagaimana anak sebaiknya mempelajarinya. Delegator adalah gaya mengajar ter- 
akhir yang benar-benar membutuhkan ide kreatif dari anak-anak untuk mempelajari sesuatu. Alat, bahan, materi, ide, dan sebagainya disediakan sendiri oleh anak, walaupun guru juga dapat membantu menyediakan apa yang anak butuhkan. Anak dan guru dapat bekerjasama untuk mempelajari sesuatu.

Ada beberapa hal yang perlu diperhatikan untuk meningkatkan gaya mengajar pendidik menurut Morgan (2002), yaitu: (1) Be in command, in charge, and supremely confident in the classroom. You are a PROFESSIONAL, after all; () Never lose your temper. Be firm, perhaps, but don't ever lose control. Deal with explosive situations at another time or another place; (3) Talk to students as if they're human beings, not predatory devils. A little respect for students goes a long way and doesn't stop you from providing advice and guidance; (4) Have a sense of humor. Be ready to laugh even at yourself at appropriate moments; (5) Be fair. "Fair" is probably the most commonly mentioned trait students use about teachers. It may be the hardest thing to do. Work at it. Ask for help from fellow teachers, administrators, and students; (6) Be a mentor or get a mentor. Find someone on the faculty you can trust to bounce ideas off of; (7) Be organized. Read any book on how to be organized that looks like it might help; (8) Try not to take problems home. Work, yes, but problems, no. Resolve them before you leave for the day or at least develop a plan for resolving them tomorrow; (9) Be prepared. Not necessarily in the Boy Scout sense, but have ready all you need for teaching before school starts. Have your lessons planned, make sure all materials are in place, and check the VCR before you show that video; (10) Be the professional with parents and administrators. Consider the concerns and requirements of others, but remember...you're a trained professional; (11) Give a little of yourself. Arrive a little early, stay a little late. Everyone on the faculty knows who comes in at the last minute and leaves just as the final bell tolls.

Dari pandangan di atas dapat dideskripsikan, bahwa seorang guru hendaknya memiliki kemampuan diantaranya percaya diri, dapat mengendalikan emosi saat berada dalam situasi pembelajaran, berbicara dengan baik dengan anak, memiliki humor, bersikap adil, menjadi mentor yang baik kepada anak, dapat mengorganisasikan kegiatan, tidak membawa masalah di rumah ke dalam kelas, menyiapkan segala sesuatu yang dibutuhkan dalam pembelajaran, menjadi professional dengan orang tua dan staf administrasi, datang beberapa menit sebelum waktu pembelajaran dimulai. Hal ini berarti, bahwa seorang guru hen-daknya memiliki kepribadian yang baik dari sisi diri sendiri dan orang lain. Kemampuan intelektual, bahasa, interpersonal dan intrapersonal, dan seni sangat dibutuhkan untuk menjadi seorang yang profesional. Dari berbagai pendapat tersebut, maka peneliti hendak memfokuskan pada gaya mengajar yang bertipe formal authority, personal model atau demonstrator, fasilitator dan delegator. Masing-masing gaya mengajar memiliki perbedaan dan persamaan yang khas dalam strategi pembelajarannya. Kecenderungan tersebut akan terungkap dalam hasil penelitian berikut ini.

\section{METODE PENELITIAN}

\section{Jenis Penelitian}

Berdasarkan metode yang digunakan, penelitian ini termasuk dalam penelitian kualitatif deskriptif. Metode deskriptif adalah data yang dikumpulkan berupa kata-kata, gambar, dan bukan angka-angka (Moleong, 2008: h. 11). Dalam penelitian ini, peneliti ingin memperoleh informasi atau gambaran yang jelas mengenai bagaimana gaya mengajar dosen PG PAUD FIP UNJ.

\section{Tempat dan Waktu Penelitian}

Penelitian ini dilakukan di Universitas Negeri Jakarta, Fakultas Ilmu Pendidikan, Jurusan/Program Studi Pendidikan Anak Usia Dini beralamat di Kampus A Jalan Rawamangun Muka Raya, Rawamangun, Jakarta Timur kode pos 13220, Gedung Daksinapati Lantai 1 Ruang 117, selama 5 bulan sejak bulan September 2011 sampai dengan Januari 2012

\section{Prosedur Penelitian}

\section{a. Sumber Data}

Sumber data penelitian adalah dosen PG PAUD sebanyak 17 orang yang mengajar mahasiswa Reguler PAUD angkatan 2011 dan 2010 semester 095 Tahun 2011, dan mahasiswa Reguler PAUD angkatan 2011 berjumlah 37 orang, serta angkatan 2010 berjumlah 28 orang.

b. Teknik Pengumpulan Data

Teknik Pengumpulan data dilakukan melalui pengamatan, angket, dan dokumentasi yang diisi oleh mahasiswa PG PAUD angkatan 2008-2011.

\section{c. Teknik Analisis Data}

Teknik analisis data menggunakan analisis kualitatif, menurut Miles dan Huberman dengan langkah-langkah sebagai berikut: (1) reduksi data, (2) display data, serta (3) kesimpulan dan verifikasi data (Sugiyono, 2010; hh. 91-99). Reduksi data adalah menjabarkan dan menyeleksi data-data yang digunakan untuk mendukung fokus dan pertanyaan penelitian. Display data adalah membuat kategori berdasarkan indikator/aspek yang diteliti dan menganalisis setiap aspek tersebut. Kesimpulan/verifikasi adalah membuat kesimpulan berdasarkan masing-masing aspek/ indikator tersebut. 


\section{HASIL DAN PEMBAHASAN}

\section{Reduksi Data}

Pertama, formal authority: (1) dosen menyuruh mahasiswa menyiapkan form 05 dan 06, (2) dosen mengucapkan salam ketika masuk kelas, (3) dosen memimpin doa sebelum mulai pembelajaran, (4) dosen mengabsen mahasiswa satu persatu, (5) dosen menanyakan materi sebelumnya, (6) dosen menjelaskan materi dan memberikan contoh secara umum, (7) dosen memberikan tugas sesuai dengan materi yang telah disampaikan, (8) dosen menegur mahasiswa yang tidak menyelesaikan tugas dan tidak mengikuti aturan, (9) dosen menilai mahasiswa, (10) dosen mengurangi nilai bagi mahasiswa yang melanggar aturan, dan (11) dosen memimpin doa setelah selesai perkuliahan. Dosen yang memiliki gaya mengajar tipe ini adalah $\mathrm{R}$ Sihadi.

Kedua, demonstrator atau personal model: (1) dosen mengucapkan salam ketika masuk kelas, (2) dosen mengabsen mahasiswa satu persatu, (3) dosen menanyakan materi sebelumnya, (4) dosen menjelaskan materi, (5) dosen menyiapkan alat dan bahan untuk praktek langsung, (6) dosen memberikan contoh tahap demi tahap cara melakukannya, (7) dosen memberikan tips yang mudah dilakukan oleh mahasiswa, (8) dosen mempersilakan mahasiswa melakukan seperti yang telah dicontohkan, (9) dosen menegur mahasiswa yang tidak menyelesaikan tugas dan tidak mengikuti aturan, dan (10) dosen menilai mahasiswa. Dosen yang memiliki gaya mengajar tipe ini adalah Myrnawati, Yenina Akmal, Tuti Syam, dan Tri Yuli Prasetyo.

Ketiga, fasilitator: (1) dosen mempersilakan mahasiswa untuk mengambil dan menyiapkan form 05 dan 06 sebelum perkuliahan berlangsung, (2) dosen mempersilakan mahasiswa untuk memimpin doa, (3) dosen mendiskusikan aturan perkuliahan bersama mahasiswa, (4) dosen dan mahasiswa mengambil keputusan bersama berdasarkan mufakat, (5) dosen menanyakan dan mendiskusikan pengetahuan dan pengalaman mahasiswa sebelum materi dimulai, (6) dosen menjelaskan materi secara umum, (7) dosen mempersilakan mahasiswa mengungkapkan ide tentang materi yang disampaikan atau pengalamannya, (8) dosen memberikan penguatan positif kepada mahasiswa secara lisan dan perbuatan, (9) dosen memberikan arahan tugas kepada mahasiswa, (10) dosen mendorong mahasiswa untuk menemukan ide baru dalam menyelesaikan tugasnya, (11) dosen membantu mahasiswa memecahkan masalah dalam menyelesaikan tugasnya, dan 12) dosen memberikan penilaian terhadap tugas dan keaktifan mahasiswa. Dosen yang memiliki gaya mengajar tipe ini adalah Gusnawirta, Yudri Jahja, Myrnawati, Anan Sutisna, Masitowati Gatot, Yuliani Nurani, Eveline Siregar, Sri Aswati, Sri Indah Pujiastuti, Endang Wahyudiana, Tuti Syam, Hapidin, Azizah Muis.

Keempat, delegator: (1) dosen mempersilakan mahasiswa menyiapkan form 05 dan 06 dan mengatur semua fasilitas perkuliahan, (2) dosen dan mahasiswa mendiskusikan materi yang akan dibahas pada mata kuliah tertentu, (3) dosen mengarahkan dan membimbing mahasiswa untuk menemukan materi yang tepat, (4) dosen mempersilakan mahasiswa melaksanakan tugas-tugas yang sudah ditentukan bersama, (5) dosen dan mahasiswa membahas temuan penelitian, (6) dosen dan mahasiswa memecahkan masalah di lapangan, (7) dosen dan mahasiswa melakukan tindak lanjut terhadap masalah di lapangan, serta (8) dosen dan mahasiswa melakukan penilaian pada kinerja masing-masing dan teman sejawat kepada dosen. Dosen yang memiliki gaya mengajar tipe ini adalah Nurbiana Dhieni.

\section{Display Data}

\section{1) Formal Authority}

Gaya mengajar ini berpusat pada dosen. Dosen yang memiliki gaya mengajar tipe ini kecenderungan merasa memiliki tanggung jawab yang besar terhadap pengetahuan dan pengalaman mahasiswa. Mahasiswa cenderung hanya menerima dan mengasimilasi pengetahuan yang disampaikan oleh dosen. Dosen tidak kreatif dalam mengemas perkuliahan baik isi maupun strategi pembelajarannya karena dosen cenderung mentransfer pengetahuan kepada mahasiswa dan mahasiswa tidak mendalaminya kembali. Tidak penting bagi dosen membangun hubungan yang kreatif dengan mahasiswa atau mahasiswa dengan mahasiswa.

2) Demonstrator atau Personal Model

Gaya mengajar berpusat pada dosen. Dosen cenderung memberikan contoh-contoh secara teoretis dan praktis kepada mahasiswa tahap demi tahap sehingga mahasiswa kemampuan dan proses pengetahuan terjadi. Dosen juga memberikan kesempatan kepada mahasiswa untuk mengembangkan apa yang sudah didemonstrasikan oleh dosen. Mahasiswa dapat melakukan atau mempraktekkan pengetahuan sesuai contoh dari dosen atau mengembangkan ide barunya. Dosen memberikan pengarahan dan bimbingan kepada mahasiswa, jika mengalami kesulitan. Di sini partisipasi mahasiswa sangat diharapkan dan memungkinkan mahasiswa menggunakan berbagai gaya belajar.

3) Fasilitator 
Gaya mengajar ini berpusat pada mahasiswa. Dosen mengarahkan fokus pada fasilitas dan kegiatan. Dosen cenderung menyediakan fasilitas yang dibutuhkan oleh mahasiswa dan kegiatan-kegiatan yang bermakna agar mahasiswa memahami pengetahuan yang dipelajari. Tanggung jawab lebih banyak diberikan kepada mahasiswa untuk berinisiatif dan menyelesaikan berbagai tugas. Mahasiswa harus mandiri, aktif, dan berkolaborasi sesama mahasiswa dalam mengeksplorasi lingkungan. Dosen merancang kegiatan yang bertipe active learning, kolaborasi antarinter mahasiswa dan memecahkan masalah.

4) Delegator

Gaya mengajar ini berpusat pada mahasiswa, dosen hanya mendelegasikan dan menempatkan pengawasan dan tanggung jawab pada pembelajaran secara individual atau kelompok. Dosen seringkali menyediakan rancangan dan implementasi pembelajaran proyek yang kompleks, dan menggunakan peran konsultasi dalam pemecahan masalah. Mahasiswa harus mampu bekerja secara mandiri atau dalam kelompok secara efektif. Mahasiswa harus mampu mengorganisasikan peran hubungan interpersonal. Jadi mahasiswa harus mampu menyelesaikan berbagai masalah yang terjadi berkaitan dengan proyek yang sedang dipelajari.

\section{Kesimpulan/Verifikasi Data:}

Pertama, Formal authority adalah gaya mengajar yang berpusat pada dosen dan bersifat ekspository (satu arah), yaitu hanya mentransfer pengetahuan kepada mahasiswa,

Kedua, Demonstrator atau Personal Model adalah gaya mengajar yang berpusat pada dosen. Dosen sebagai model utama atau contoh teladan harus dapat ditiru oleh mahasiswa,

Ketiga, Fasilitator adalah gaya mengajar yang berpusat pada mahasiswa. Dosen menyiapkan berbagai kegiatan yang dapat dilakukan oleh mahasiswa. Mahasiswa harus dapat menggali berbagai pengetahuan dari kegiatan yang diberikan oleh dosen,

Keempat, Delegator adalah gaya mengajar yang berpusat pada mahasiswa. Dosen memberikan proyek yang kompleks, sehingga mahasiswa dapat belajar dari proyek tersebut baik secara individual maupun kelompok. Peran konsultasi kepada dosen diperlukan untuk pemecahan masalah. Mahasiswa harus mampu memanage segala sesuatu yang terjadi dalam proyek tersebut.

\section{PENUTUP}

\section{Kesimpulan}

Berdasarkan hasil penelitian, menunjukkan kecenderungan dosen PG PAUD FIP UNJ adalah menggunakan gaya mengajar fasilitator. Gaya mengajar ini berpusat pada mahasiswa dan mengarahkan mahasiswa untuk melakukan berbagai kegiatan yang telah disediakan dosen. Mahasiswa diharapkan mampu meningkatkan dan mengembangkan kemampuannya baik secara individual maupun kelompok. Gaya mengajar fasilitator sesuai dengan kebutuhan mahasiswa karena mahasiswa dalam tahap masa dewasa yang harus mampu memecahkan masalah dalam kehidupannya secara mandiri. Berdasarkan pendapat terbanyak menurut mahasiswa dan temuan lapangan, maka disimpulkan, bahwa gaya mengajar dosen PG PAUD FIP UNJ adalah fasilitator. Urutan berikutnya adalah: (1) personal model atau demonstrator, (2) formal authority, dan (3) delegator. Formal authority dan delegator hanya memiliki masing-masing satu orang yang mewakili.

\section{Implikasi}

Implikasi penelitian ini bagi dosen adalah dosen PG PAUD FIP UNJ harus mampu meningkatkan dan mengembangkan kemampuannya dalam merancang kegiatan yang kreatif sehingga mahasiswa semakin termotivasi untuk belajar, misalnya dalam menentukan strategi pembelajaran yang tepat mulai dari tujuan, materi, metode, media, kegiatan belajar mengajar, dan evaluasi. Selain itu, kompetensi lain yang harus ditingkatkan adalah personalitas, sosial, dan profesional. Selain gaya mengajar fasilitator, ada baiknya jika dosen PAUD juga menggunakan gaya mengajar delegator untuk meningkatkan kreativitas mahasiswa dalam memecahkan masalah di lapangan, sehingga pembelajaran tidak harus selalu di dalam kelas.

Implikasi bagi mahasiswa adalah mahasiswa harus siap melakukan dan menyelesaikan tugas-tugas yang berkaitan dengan pembelajaran. Jika dosen menggunakan gaya mengajar yang berpusat pada mahasiswa, maka mahasiswa harus mampu memecahkan masalah secara mandiri, aktif dalam belajar, dan mampu bekerja sama dengan berbagai pihak. Mahasiswa harus lebih kreatif menemukan ide dan hasil yang menarik atau mampu membantu pemecahan masalah di lapangan saat ini. Dengan demikian, mahasiswa dapat berguna bukan saja untuk dirinya sendiri tetapi juga bagi masyarakat luas.

\section{Saran}

Saran dapat diberikan kepada: pertama, diharapkan dosen PG PAUD FIP UNJ lebih banyak menggunakan gaya mengajar yang berpusat mahasiswa daripada yang berpusat pada dosen. Kedua, diharapkan mahasiswa PG PAUD FIP UNJ dapat lebih kreatif 
dalam meningkatkan dan mengembangkan kemampuannya di perkuliahan. Ketiga, diharapkan Jurusan PG PAUD FIP UNJ dapat memotivasi para dosen dan mahasiswa dalam meningkatkan pembelajaran dalam kampus maupun di luar kampus. Keempat, diharapkan Fakultas Ilmu Pendidik-an dapat mendukung penelitian yang dilakukan oleh para dosen PAUD dalam meningkatkan Tridarma perguruan tinggi. Kelima, diharapkan Universitas Negeri Jakarta memberikan dukungan spiritual dan materiil bagi mahasiswa dan dosen dalam mengembangkan Tridarma perguruan tinggi.

\section{DAFTRA PUSTAKA}

Felder, R. M., \& Solomon, B.A. (1992). Teaching styles and learning in a quantitative classroom. California: North Carolina State University.

Moleong, L.J. (2008). Metodologi penelitian kualitatif. Jakarta: Rosda Karya.

Morgan, K. (2002). Teaching styles, progression and variety in athletics lessons. British Journal of Teaching Physical Education. 34(1), 12-14. (Great Britain).

Sugiyono. (2010). Metodologi penelitian pendidikan pendekatan kuantitatif, kualitatif, dan $R \mathcal{E} D$. Bandung: Alfabeta. 